\title{
Effect of Drought and Elevated Temperature on Micronutrient Accumulation in Wheat (Triticum aestivum L.) Grain
}

\author{
Satish Kumar $^{1 *}$, Pankaj Kumar ${ }^{1}$, Santosh Kumar Singh ${ }^{2}$ and Rajeev Kumar ${ }^{1}$ \\ ${ }^{1}$ Department of Agricultural Biotechnology and Molecular Biology, DRPCAU, \\ Pusa, Bihar - 848125, India \\ ${ }^{2}$ Department of soil science, DRPCAU, Pusa, Bihar-848125, India \\ *Corresponding author
}

\begin{tabular}{|l|}
\hline K e y w o r d s \\
$\begin{array}{l}\text { Wheat (Triticum } \\
\text { aestivum L.), Grain }\end{array}$ \\
\hline Article Info \\
\hline $\begin{array}{l}\text { Accepted: } \\
\text { 20 March } 2018 \\
\text { Available Online: } \\
10 \text { April } 2018\end{array}$ \\
\hline
\end{tabular}

\section{A B S T R A C T}

Micronutrients are essential for human health and crucial for plant survival. Increasing temperature and drought are major abiotic stress which limits the productivity and nutritional quality of wheat. The objective of study is to evaluate effect of heat stress and elevated temperature on micronutrient $(\mathrm{Zn}, \mathrm{Cu}, \mathrm{Fe}$, and $\mathrm{Mn}$ ) content in wheat (Triticum aestivum L.) grain. The 18 wheat varieties were accessed and evaluated for variations of micronutrient accumulation in there mature grains under two different environmental conditions. Pot experiments were carried out during rabbi 2011-12 at RAU, Pusa Bihar. Generally, elevation in temperature reduces the accumulation of $\mathrm{Zn}, \mathrm{Cu}, \mathrm{Fe}$ and $\mathrm{Mn}$ level in grains but some varieties enhances the accumulation of micronutrients under heat stress condition significantly. The wheat varieties Kauz/AA/Kauz, F5-995, Halnaand MonsAld's are good accumulator for $\mathrm{Zn}$ in grains. The accumulation of $\mathrm{Cu}$ was increased in grains of Halna, Kauz/AA/Kauz, and F5-99, whereas, AKAW 4008, Halna, PBW343 Kauz/AA/KauzandRaj 3765has good accumulation property of $\mathrm{Fe}$ in there grains. The enhanced $\mathrm{Mn}$ accumulation under high temperature was observed in grains of variety AKAW4008, Halna, Kauz/AA/Kauz and F5-995. The wheat variety Kauz/AA/Kauz, F5995, PBW343, Halna and Raj 3765showed overall better micronutrients accumulation in there grains under stress condition and appeared as potentially important wheat variety to reduce the problem of malnutrition

\section{Introduction}

Wheat is the second most produced cereal crop and consume in many parts of the world. Wheat is important source of protein and energy (Braun et al., 2010). Wheat grain contains all essential nutrients including carbohydrates (60-80\% mainly as starch), proteins $(8-15 \%)$ containing adequate amounts of all essential amino acids except lysine, tryptophan and methionine, fats (1.5-2\%), minerals (1.5-2\%), vitamins (B complex and vitamin E) and $2.2 \%$ crude fibres. Food and nutritional security is challenged for increasing population and increasing demand for nutritious and healthy food due to changing food habits and growing middle class income (Velu et al., 2016). Food and nutritional security will be reduced by climate change in warmer temperatures and reduced 
water availability in most spring wheat growing environments (FAO, 2015).World population reach 9.7 billion by $2050,33 \%$ higher than today, mostly all of this population increase will occur in developing countries (FAO, 2015). Malnutrition is major problem in the world and the number of chronically undernourished and malnourished people in the world increased regularly (Welch and Graham, 2004). Black et al., 2013 reported that about 26 percent of the world's children are stunted, 2 billion people suffer from one or more micronutrient deficiencies and 1.4 billion people are overweight, of whom 500 million are obese.

A number of environmental factors such as temperature, moisture, soil and light intensity affect the growth and yield of wheat (Keresa et al., 2001). Temperature and nutrient are two major components of environmental variation that provide significant limitation to a successful crop production. Zn, Fe, Mn, and $\mathrm{Cu}$ are essential micronutrient in both plant and animal. The accumulation of minerals in edible seeds depends on a series of complex processes: the ion availability in soils, uptake efficiency by roots, translocation to the shoots, uptake and storage in the seeds (Grusak and Della Penna, 1999; Olsen and Palmgren, 2014). Iron deficiency mainly causes anemia is the most widespread micronutrient deficiency and it results in stunted physical growth as well as mental retardation, decreased learning capacity in human (Bouis et al., 2011) and induced chlorosis in plant. Human $\mathrm{Zn}$ deficiency is the fifth major cause of disease and deaths (WHO, 2002). Around the world 2.7 billion people are $\mathrm{Zn}$ deficient (WHO, 2002; Muller and Krawinkel, 2005) About $50 \%$ of the world population is under the risk of $\mathrm{Zn}$ deficiency and prevalence is more in developing countries of Asia and Africa (Maret and Sandstead, 2006). Zn activates various enzymes, especially carboxylases and needed in the synthesis of auxin in plants that act synergistically in wheat (Khurana and Chatterjee, 2000). Furthermore, $\mathrm{Zn}$ and $\mathrm{Fe}$ bioavailability in seeds is strongly reduced by phytate, a hexaphosphorylated inositol that serves as a storage form of phosphorus in seeds. Copper is also essential micronutrient and vital in the body as a component of (cofactor) for enzyme systems involved in iron transport and metabolism, red blood cell formation and immune function. United States recommended that supplement broiler and swine diets with 125 to $250 \mathrm{ppm}$ additional copper to enhance health and growth. Mainly pregnant women and children below the age of five are affected due to malnutrition. Biofortification is approach is used to alleviate deficiencies of these mineral nutrients in staple food crops with essential minerals and vitamins (Welch and Graham, 2004; Bouis et al., 2011 and Cakmak et al., 2010) and most common approach to increase micronutrients in staple crops is by applying fertilizers rich in $\mathrm{Zn}, \mathrm{Mn}$ and $\mathrm{Fe}$ and $\mathrm{Cu}$ but this approach requires some technology and money. Improving the nutritional levels of wheat is therefore of paramount importance. Climate change and related abiotic stresses such as drought and elevated temperature will likely affect nutritional quality of wheat grain. Therefore, this study set out to establish the effect of drought and elevated temperatures on grain nutritional factors association with different wheat varieties under stressed and normal conditions.

\section{Materials and Methods}

\section{Plant material and growth conditions}

Plant material for micronutrients analysis study includes eighteen wheat variety maintained under RKVY. Project titled: Enhancement of heat tolerance in locally adapted wheat cultivars of Bihar" in department of Agricultural Biotechnology and 
Molecular Biology, DRPCAU, Pusa, Bihar. Seeds were washed in distilled water and sterilized by immersion in mercury dichloride solution (1:1000) for two minutes. The seed were next washed five times in deionizer water and placed in an oven at $28^{0} \mathrm{C}$ for 24 hours. After that the seeds were grown in greenhouse in $24 \times 21 \mathrm{~cm}$ pots containing soils. The experiment was conducted using 108 pots. 18 wheat varieties were sown in plastic pot using completely randomized design (CRD) in six replications. During the vegetative growth plant were kept under similar environment conditions. Half of the pots, three replications of each of the 18 wheat varieties were shifted under poly house condition to provide heat stress before booting. For each varieties 6 replication were used (Three heat stress and three in natural condition). During the period of experiment the position of the pot was changed weekly, to minimize the effects due to irradiance variations. Plants were irrigated weekly to $1 / 2$ Hoagland solution as per schedule and requirement. Maximum and minimum temperatures $\left({ }^{0} \mathrm{C}\right)$ as well as relative humidity (\%) were recorded during the crop growth period.

\section{Nutrient analysis}

The accumulation of micronutrients ( $\mathrm{Fe}, \mathrm{Zn}$, $\mathrm{Cu}$ and $\mathrm{Mn}$ ) was determined in wheat (Triticum aestivum L.) grain. The plant samples were washed with $0.2 \%$ liquid detergent solution, than with $0.1 \mathrm{~N} \mathrm{HCl}$ solution $(0.1 \mathrm{~N} \quad \mathrm{HCl}$ removes metallic contaminants) and finally with deionized water (Deionized water washes the previous two solutions). After that the extra moisture was wiped out, the sample was placed in new paper bags and dried in an oven at $70^{\circ} \mathrm{C}$. Wheat grain digested following the methods given by Hatcher and Wilcox (1950). $100 \mathrm{mg}$ sample was digested in diacid mixture (HNO3:HClO4, 10:4) on a rectangular hot plate. After the completion of the digestion the colour become milky white. It was filtered through Whatman filter paper and volume was made up to $50 \mathrm{ml}$ by adding double distilled water. After that the volume was ready for nutrient analysis. A double beam Atomic Absorption Spectrophotometer (AAS) (Perkin Elmer USA) was used for the purpose and data was collected.

\section{Statistical analyses}

Graph and One-way Analysis of Variance (ANOVA) was carried out using graph pad prism statistical software version 5.01. Values presented were means \pm standard error (SE) of three replicates in each group. P-values $\leq 0.05$ were considered as significant.

\section{Results and Discussion}

Micronutrient uptakes in stressed plants were below to unheated plant, but in severelystressed plants, levels of $\mathrm{Fe}, \mathrm{Zn}, \mathrm{Cu}$ and $\mathrm{Mn}$ increased in compression to unheated plant.As depicted in Figure.1, Fe content significantly increases up to 227.3,226.2,178.3,139.7,138.1 ppm in varieties namely Kauz/ AA/Kauz, Raj3765, Halna, AKAW4008 and PBW343 respectively under stress condition earlier same pattern was observed by Cakmak et al., (2000) and Dias et al., (2009) in their line of study while higher reduction of $\mathrm{Fe}$ is found in variety HD2888 (85.56 ppm) as compared to normal similar result was reported by Welch and Graham 2004 and Velu et al., 2016). Several studies were carried out at CIMMYT to examine the effect of soil and climatic factors (i.e. the environment) on grain-Fe and grain- $\mathrm{Zn}$ concentrations in wheat genotypes. $\mathrm{Zn}$ content gradually decreases while increased temperature the means of relative ranges for grain $\mathrm{Zn}$ tended to be higher in variety Halna, MonsAld's, F5-995, MB4010, Sonalika, Kauz/AA/Kauz and Raj 3765at high temperature presented in Figure 2. 


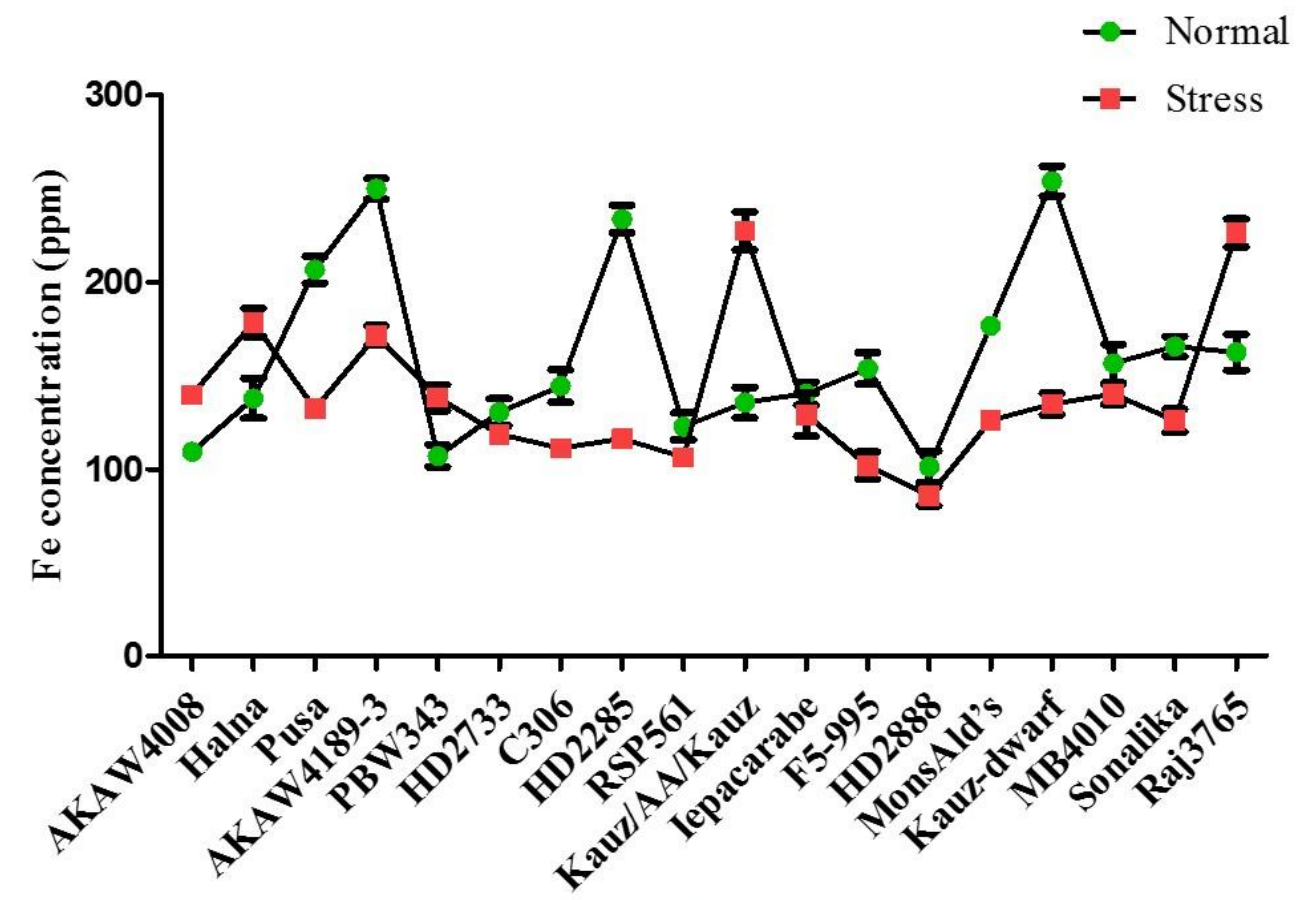

Figure 1. Effect of Drought and Elevated temperature on grain Fe Concentration of wheat grown under natural and stress condition

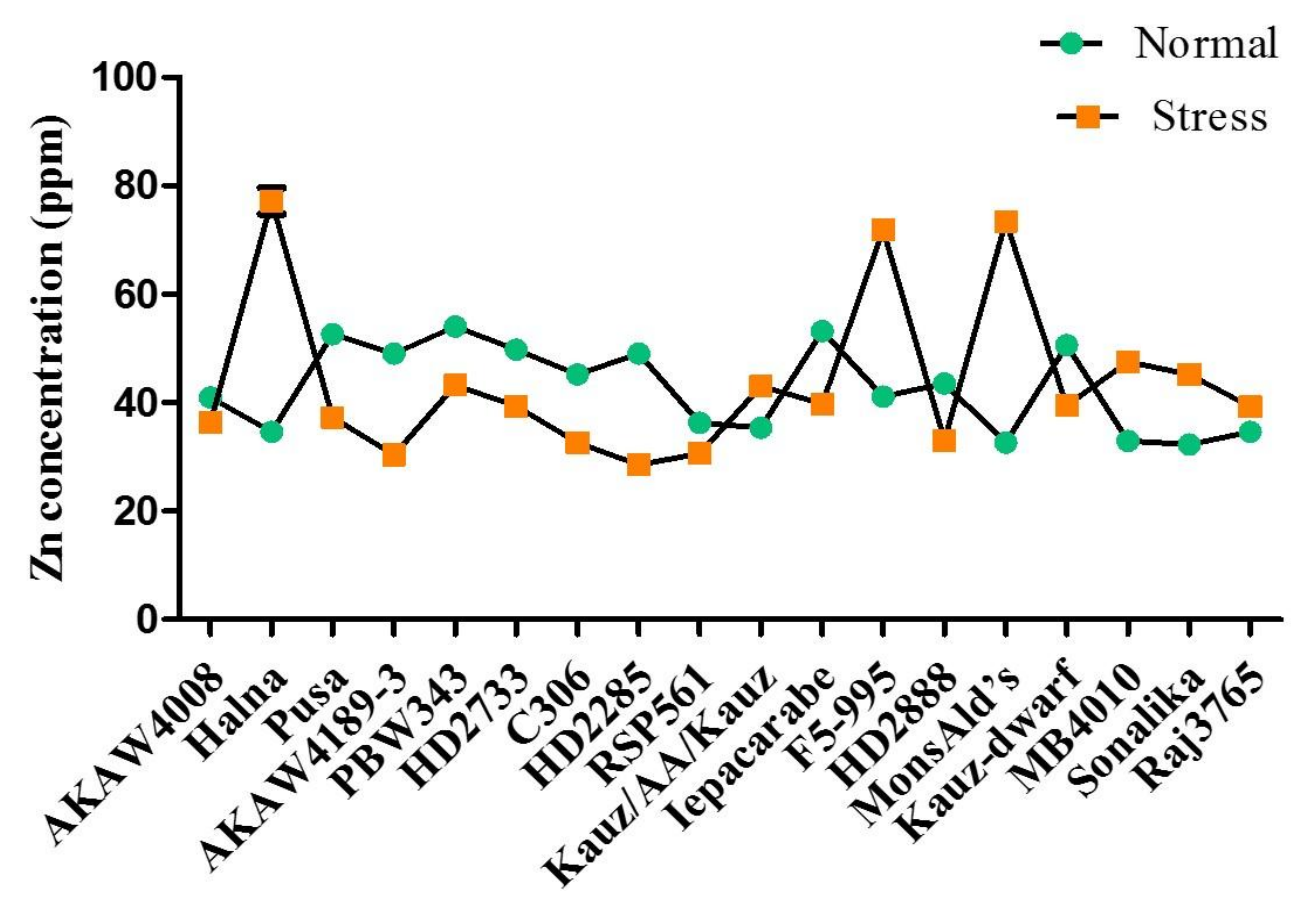

Figure 2. Effect of Drought and Elevated temperature on grain $\mathrm{Zn}$ Concentration of wheat grown under natural and stress condition 


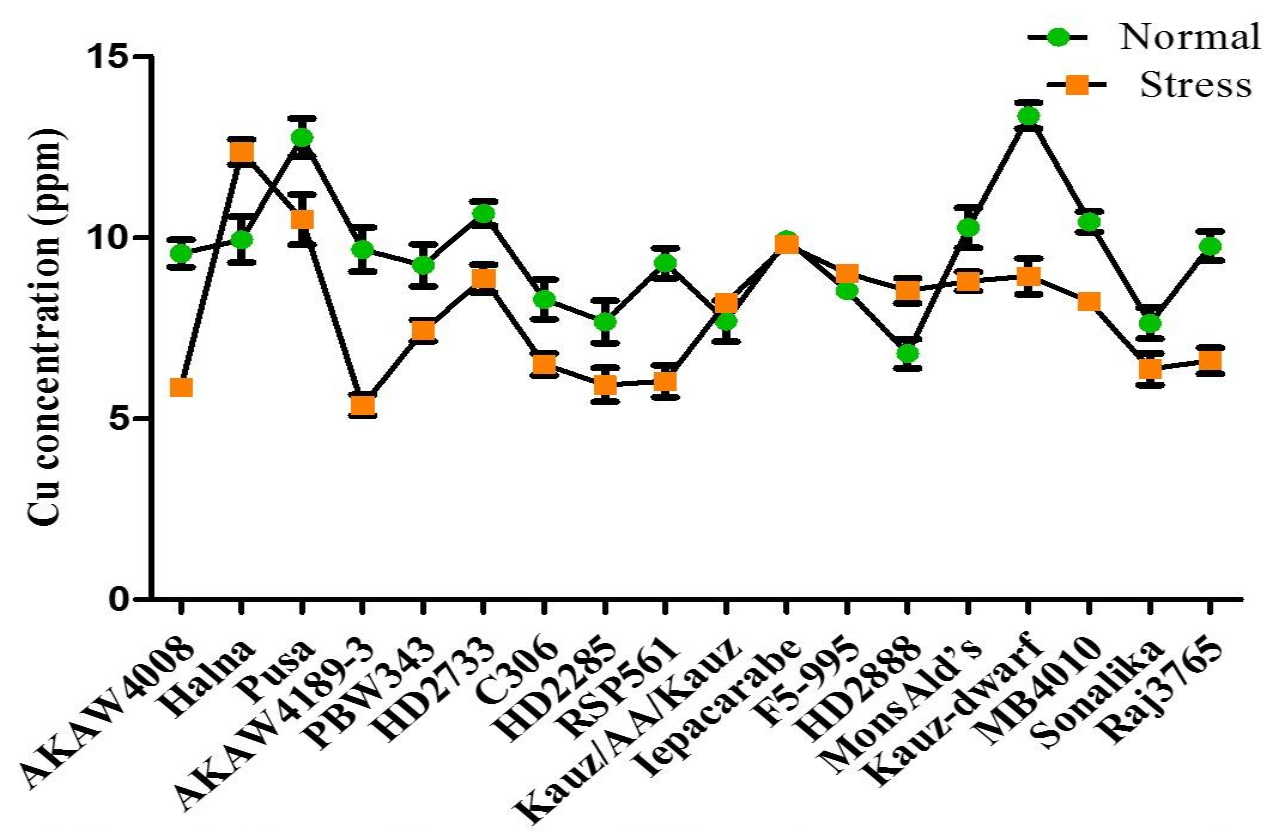

Figure 3. Effect of Drought and Elevated temperature on grain $\mathrm{Cu}$ Concentration of wheat grown under natural and stress condition

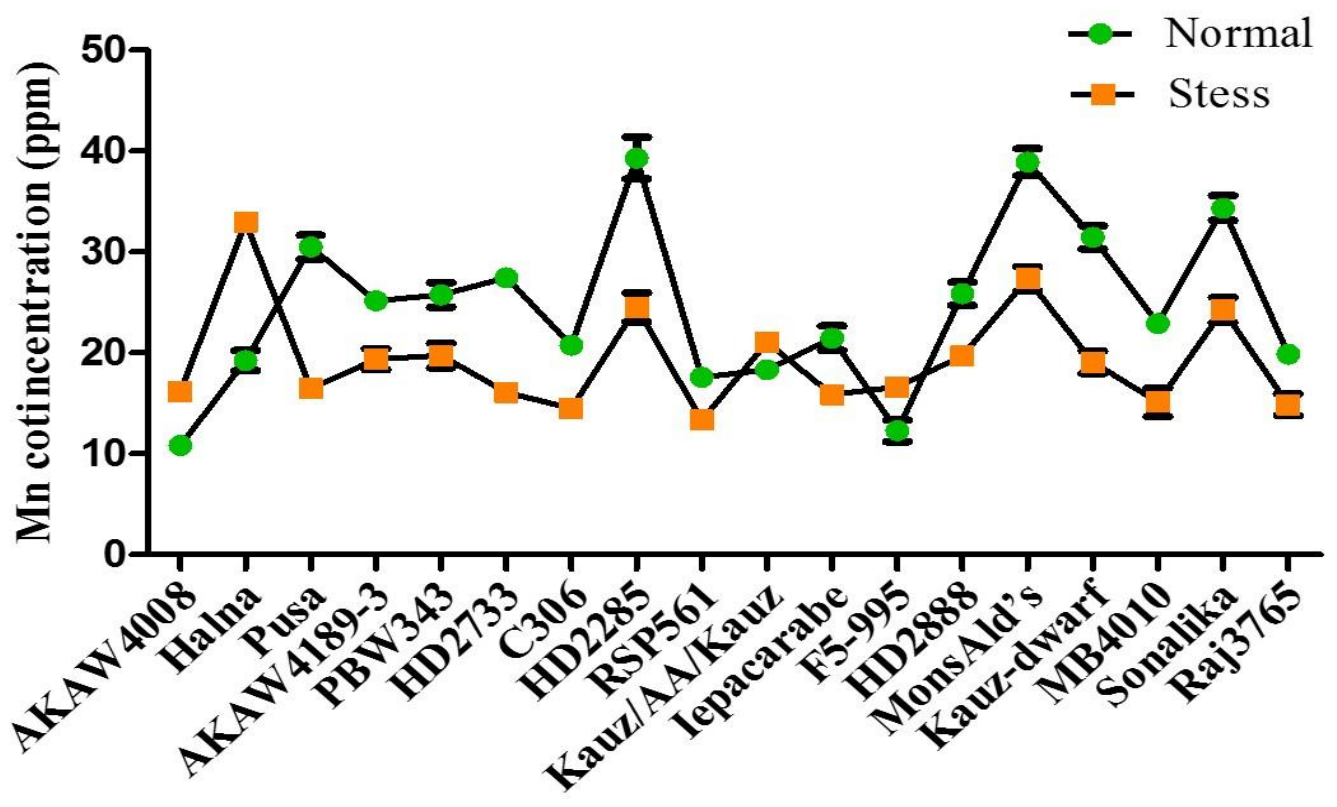

Figure 4. Effect of Drought and Elevated temperature on grain Mn Concentration of wheat grown under natural and stress condition

More contents of $\mathrm{Zn}$ under heat stress condition recorded significantly in varieties namely Halna $(77.2 \mathrm{ppm})$ and MonsAld's, (73.46 ppm) respectively. Similar results was reported by Velu et al., (2016) in megavariety 'PBW 343' showed about $20 \% \mathrm{Zn}$ increase in stressed environments. 
Figure. 3 represent the mean value and the SE the accumulation of copper under heat stress has significantly increased in variety Halna (12.36ppm) F5-995 (8.1 ppm) and Kauz/AA/Kauz (9.02)whereas varieties Kauzdwarf (13.36 ppm) and Pusa gold (12.76 ppm) have accumulated significantly more copper under normal condition than that of in heat stress condition. The remaining varieties namely AKAW4189-3, PBW343, HD2733, C306, HD2285, RSP561, MonsAld's, MB4010 and Raj3765, there have been no significant differences in the accumulation of copper under normal and heat stress condition (Fig. 4).

Results showed that under heat stress condition the copper accumulation has not significantly increased in seed; however the stress has not significantly affected the accumulation of copper same pattern was reported by Dias et al., (2009). As a general pattern that $\mathrm{Cu}$ contents increased in the different parts of the heat stressed plants, following patterns was also noticed by Garnett and Graham 2005 and Dias et al., (2009). In both condition (normal and stressed) the value is non- significant the similar result was found by Dias et al., 2009.

Varieties AKAW4008, Halna, F5-995 and Kauz/AA/Kauz (16.19, 32.96, 21.06 and 16.66 ppm respectively) the accumulation of $\mathrm{Mn}$ in heat stress condition has increased significantly while in varieties namely C306,Kauz-dwarf and MB4010 the value has significantly decreased. However in remaining varieties namely Pusa gold, AKAW4189-3, HD2733, RSP561, and Raj3765 there have been no effect of heat stress on manganese accumulation the accumulation of Manganese in heat stress condition has significantly increased as earlier reported by Dias et al., (2009) while in varieties namely C306, Kauz-dwarf and MB4010 the value has significantly decreased similar pattern reported by Dikeman et al., (1982), Dias et al., (2009). Chen et al., (2016) also reported that micronutrients bioavailability is strongly reduced in seeds.

\section{Acknowledgment}

The authors are thankful to DBT for providing financial support in the form of Research Fellowship during the course of my study and provide fund for my research work. We would like to thanks Dr. V. K. Shahi Dean of FBSandH PUSA and all faculty members of AB and $\mathrm{MB}$ for their support during this research work.

\section{References}

Black, R. E., Victora, C. G., Walker, S. P., Bhutta, Z. A., Christian, P., De Onis, M., Ezzati, M., Grantham-McGregor, S., Katz, J. and Martorell, R. (2013). Maternal and child under nutrition and overweight in low-income and middleincome countries. The lancet, 382(9890), 427-45

Bouis, H. E., Hotz, C., McClafferty, B., Meenakshi, J. V. and Pfeiffer, W. H. (2011). Biofortification: a new tool to reduce micronutrient malnutrition. Food and Nutrition Bulletin, 32(1_suppl1), S31-S40.

Braun, H.-J., Atlin, G. and Payne, T. (2010). Multi-location testing as a tool to identify plant response to global climate change. Climate change and crop production, 1, 115-138

Cakmak, I., Kalayci, M., Kaya, Y., Torun, A. A., Aydin, N., Wang, Y., Arisoy, Z., Erdem, H., Yazici, A. and Gokmen, O. (2010). Biofortification and localization of zinc in wheat grain. Journal of Agricultural and Food Chemistry, 58(16), 9092-9102.

Cakmak, I., Ozkan, H., Braun, H. J., Welch, R. M. and Romheld, V. (2000). Zinc and iron concentrations in seeds of wild, primitive, and modern wheats. Food and Nutrition Bulletin, 21(4), 401-403

Chen, X., Yuan, L. and Ludewig, U. (2016). Natural Genetic Variation of Seed Micronutrients of Arabidopsis thaliana Grown in Zinc-Deficient and Zinc- 
Amended Soil. Frontiers in plant science, 7, 1070.

Dias, A. S., Lidon, F. C. and Ramalho, J. C. (2009). IV. Heat stress in Triticum: kinetics of $\mathrm{Fe}$ and $\mathrm{Mn}$ accumulation. Brazilian Journal of Plant Physiology, 21(2), 153-164

Dias, A. S., Lidon, F. C., and Ramalho, J. C. (2009). Evaluation of grain filling rate and duration in bread and durum wheat genotypes as affected by sowing dates and high temperature stress. Pak. J. Bot., 37(3): 575-584.

Dias, A. S., Lidon, F. C., and Ramalho, J. C. (2009). Heat stress in Triticum: Kinetics of $\mathrm{Cu}$ and $\mathrm{Zn}$ accumulation. Brazilian $\mathrm{J}$. plant physiol., 21(2): 135-142

Dikeman, E., Pomeranz, Y. and Lai, F. S. (1982). Minerals and protein contents in hard red winter wheat. Cereal Chemistry (USA).

FAO, 2015. FAOSTAT. www.fao.org.

FAO, 2015. The State of Food Insecurity in the World, pp. 1e56. www.fao.org

Garnett, T. P. and Graham, R. D. (2005). Distribution and remobilization of iron and copper in wheat. Annals of Botany, 95(5), 817-826.

Grusak, M. A. and Penna, D. D. (1999). Improving the nutrient composition of plants to enhance human nutrition and health Annu. Rev. Plant Physiol. Plant Mol. Biol, 1999, 133-61.

Hatcher, J. T. and Wilcox, L. V. (1950). Colorimetric determination of boron using carmine. Analytical chemistry, 22(4), 567-569

Hoagland, D. R. and Arnon, D. I. (1950). The water-culture method for growing plants without soil. Circular. California agricultural experiment station, 347(2nd edit)

Keresa, S. A., Baric, M., Sarcevic, H. Marchetti, S. and Drezner, G. (2001). Callus induction and plant regeneration from immature and mature embryos of winter wheat (Triticum aestivum L.) genotypes. XVIth EUCARPIA Congress" Plant Breeding: Sustaining the Future

Khurana, N. and Chatterjee, C. (2000). Deficiency of manganese is alleviated more by low zinc than low copper in wheat. Communications in soil science and plant analysis, 31(15-16), 2617-2625

Maret, W. and Sandstead, H. H. (2006). Zinc requirements and the risks and benefits of zinc supplementation. Journal of Trace Elements in Medicine and Biology, 20(1), 3-18

Muller, O. and Krawinkel, M. (2005). Malnutrition and health in developing countries. Canadian Medical Association Journal, 173(3), 279-286.

Olsen, L.I., and Palmgren, M.G. (2014). Many rivers to cross: the journey of zinc from soil to seed. Front. PlantSci. 5:30. doi:10.3389/fpls.2014. 00030

Velu, G., Guzman, C., Mondal, S., Autrique, J. E., Huerta, J. and Singh, R. P. (2016). Effect of drought and elevated temperature on grain zinc and iron concentrations in CIMMYT spring wheat. Journal of Cereal Science, 69, 182-186

Welch, R. M. and Graham, R. D. (2004). Breeding for micronutrients in staple food crops from a human nutrition perspective. Journal of experimental botany, 55(396), 353-364.

\section{How to cite this article:}

Satish Kumar, Pankaj Kumar, Santosh Kumar Singh and Rajeev Kumar. 2018. Effect of Drought and Elevated Temperature on Micronutrient Accumulation in Wheat (Triticum aestivum L.) Grain. Int.J.Curr.Microbiol.App.Sci. 7(04): 2312-2318. doi: https://doi.org/10.20546/ijcmas.2018.704.265 